\title{
Eighteenth Amendment in the Constitution of Pakistan: Success and Controversies
}

\author{
Mahboob Hussain \\ Assistant Professor, Department of History, University of the Punjab \\ Quaid-i-Azam Campus, Lahore, Pakistan \\ Tel: 92-42-3586-7755 E-mail: profmahboob@yahoo.com \\ Rizwan Ullah Kokab (Corresponding author) \\ Assistant Professor, Department of History and Pakistan Studies, G. C. University \\ Faisalabad, Pakistan \\ Tel: 92-300-695-6680 E-mail: rizwanuk1@yahoo.com
}

Received: June 27, 2011

Accepted: August 9, $2011 \quad$ Published: January 1, 2012

doi:10.5539/ass.v8n1p81

URL: http://dx.doi.org/10.5539/ass.v8n1p81

\begin{abstract}
The paper is a critical analysis of the $18^{\text {th }}$ Amendment in the Constitution of Pakistan. The Amendment made after months of deliberations and consensus of a committee represented by all political parties in the parliament has, as claimed by its authors, cleaned the Constitution with the later undemocratic additions and deletions. The paper examines how the Amendment has undertaken different issues concerning to the strength of democracy, institutions and federation of Pakistan. The paper observes the concerns, purposes and impacts of not less than all changes made in the Constitution in the domains of democracy, civil rights, strength of parliament, provincial autonomy, decrease in the powers of President, political parties, and appointment of election commission and judiciary. Having observed its achievements an overview of the controversies, which arose in the result of the Amendment, has been taken.
\end{abstract}

Keywords: Constitution, Legislature, Amendment, Democracy

\section{Introduction}

Pakistan's constitution of 1973 has gone through various amendments since its enforcement. Even the parliament that created it introduced six amendments in it within the period of four years. Seventh amendment, a temporary one providing for a referendum was passed under the same head of government, Z. A. Bhutto but by newly elected National Assembly that had come into existence in the result of the controversial elections of 1977. Eighth Amendment paved the way for the presidential superiority over the Prime Minister and was introduced by the Assembly that came into being under the martial law order of General Zia-ul-Haq. The remaining amendments upto the $17^{\text {th }}$ one were introduced by the democratic governments from time to time. Seventeenth Amendment was imposed after compromise between the military regime of General Pervez Musharraf and political strata which came into power through 2002's general election.

Undoubtedly through the Eighteenth Amendment a serious effort has been made to settle many issues. The government is jubilant that it has scored another success through its unanimous passage. It looks as if history was made when Mian Raza Rabbani led the Parliamentary Committee on Constitutional Reforms signed its draft. It was also dubbed the best constitutional package after the 1973 Constitution as it had a great deal of resemblance to the original 1973 Constitution, as it, like the Constitution, was unanimously passed by the Parliament. (Tharani, 2010)

It was observed that "for the first time in the constitutional history of Pakistan, the President surrendered his powers to the Prime Minister voluntarily. (http://geo.tv/urdu.htm) Moreover it was maintained that for the first time politicians showed astonishing unity, maturity and extraordinary tolerance towards each other's point of view. 
For the role in passage of the Amendment the media too was praised for not creating controversies during the parliamentary considerations over it. (Malik, 2010)

In the following parts of this paper a comparative study of the eighteenth amendment that was adopted by the parliament of Pakistan would be made. The new additions and deletions would be compared with former provisions of the constitution. The implications of the amended provisions would also be observed in the light of the statements of constitutional experts, political leaders and analysis of the researchers of this paper. Most of the data has been collected from the press and analytical approach has been applied during processing of the data. The paper thus would serve as a first hand research analysis of the most important amendment in the Constitution of Pakistan namely the Eighteenth Amendment.

\section{Connection with the Democracy}

The most important achievement of the Eighteenth Amendment is the overwhelming attachment with the democracy and abhorrence with the dictatorial rule. The amendment paves the way for democratic rule in the future and tries to block all the ways, which were used in the past to derail the democratic system. "It is the beginning of the democratic era in the country," said Senator Rabbani who piloted it. (http://geo.tv/urdu.htm) It repeals the Legal Framework Order 2002 as well as Chief Executive's Orders of 2002 and declares that they were made without lawful authority. It also repeals the Seventeenth Amendment which was passed during the government of Gen. Musharraf. All of these laws have been observed as the encroachments in the constitution made under military ruler and repealing them means the proclamation that there is no place for dictatorship at least in the pages of the constitution of Pakistan. The desire to purify at least the pages of the constitution if not its effects from the additions and amendments made by the army rulers was so great that articles (i.e. 51, 59 and 62) having the same effect have either been re-written or re-phrased with mild alterations.

In order to block the way of any mischief with the sanctity of constitution, the suspension and holding in abeyance of the constitution along with its abrogation and subversion have also been added in the list of the forms of high treason. These newly inserted terms - suspension and holding in abeyance - are those which were used in the proclamations made at the time of military coups of 1979 and 1999. Thus by including these terms an effort has been made that the possible ways of taking some concession from the written law for legitimacy of military take over may be hindered. Again for the prevention of acts of damage to the constitution, it has been added that the collaborators of coups would also be dealt in the same manner as the doers themselves. It was also fixed that such high treason would not be validated by any court including Supreme Court and High Court.

Since Ayub era the powers of emergency has been a tool in the hands of military rulers. To prevent any such measure the imposition of emergency has been made more difficult. In the new arrangement the proclamation of emergency will have to be approved by both houses of the Parliament separately, not in joint session which may be easier than this. If President alone decides for the imposition of emergency it would be more difficult because this approval of both houses is obligatory to be taken within only ten days.

\section{Civil Rights}

Second attainment of the Eighteenth Amendment is the fair treatment with the fundamental rights. Rights of education, fair trial and information have been added in the constitution and the clauses about right of association have been repaired. A fair trial and due process has been made obligatory in case of arrest and detention. The constitution for the first time provides, through the insertion of a new article 19A the right of information under which every citizen has the right to have access to information in all matters of public importance. Again for the first time the duty of state for education to all children of age 5 to 16 years has been included in the constitution.

Along with the interest of Pakistan, the disturbance of public order as a restriction on the right of association had been added through the Chief Executive Order No. 24 of 2002. A restriction through which political parties could be exploited on the charges of promotion of sectarian, ethnic, regional hatred or animosity and militancy had also been pub in. The $18^{\text {th }}$ Amendment removed these restrictions plainly. Likewise a likely instrument to manoeuvre politicians through allegation of disruption of public order has been finished when the crime of public disorder has been deleted from the crimes which disqualify any person to become a Member of Parliament.

\section{Compensation to Deprived Classes and Provinces}

Another accomplishment of the Eighteen Amendments is that it also boasts to compensate the deprived and down trodden parts and classes of Pakistan. It has managed to redress the under representation of any class or area in the service of Pakistan. Arrangements were made lawful and possible so that they might not be taken as a 
discrimination against any other class or area. Through these the deprived classes and areas could be redressed under the umbrella of constitution. The security to the shares of all provinces in all federal services has been provided through the insertion of a sub-clause in Article 38. Likewise the constitutional guarantee has been provided that any omission in federal services in the past would be rectified.

Though the opposition politicians like Ghinwa Bhutto, the chairperson of PPP-SB, viewed that 18th amendment did not guarantee rights of provinces (Dawn, 2010, April 5) yet too many measures have been adopted in the $18^{\text {th }}$ Amendment, which provide the provinces the chances to flourish and keep their rights protected. In order to remedy the conflict among the provinces, the Council of Common Interest (CCI) will have a permanent secretariat and it shall meet compulsorily at least once in thirty days. Moreover the Prime Minister, on urgent matters of conflict or row among the province would be able to convene a meeting of CCI on the request of a Province. The CCI has been authorised as an arbiter for the resolution of the disputes on electricity which may arise among federal or provincial governments. Similarly the National Economic Council (NEC) has been assigned with another function of ensuring 'balanced development and regional equity.' To continue its function, now it is binding on the NEC to meet at least twice in a year. To keep them activate both the CCI and NEC have been obligated to submit their annual report to the Parliament.

The Centre's grip over the resources of the provinces has been loosened through the $18^{\text {th }}$ Amendment. The Federal government now, through insertion of a new provision in 157 (1) will have to consult the concerned provincial government before taking a decision to construct hydro-electric power station in any province. Equally the right of the provinces on the net proceeds of the duty on oil has been recognised under inclusion of 160 (1) (b). Now the provinces will receive this duty collected by the Federal Government. This duty, like that on gas, will not become the part of Federal Consolidated Fund. Moreover the decisions of previous NFC Award ( ${ }^{\text {th }}$ NFC Award), which allocated more resources to the provinces especially to Balochistan, were made the part of the constitution. Similarly now the provincial governments will have to get ratified by the provincial assembly within 60 days the entrusting of functions of any subject to the federal government.

Politically too the provinces have been made more autonomous than before. The governor of any province would be the voter and resident of the same province and shall not be taken from any other province. For the imposition of emergency in a province, the requirement of a resolution of the concerned provincial assembly has also limited the dominance of the Federation and increased the muscle of the provinces.

The spellings of the names of two provinces written in the article 1 of the Constitution of Pakistan have been corrected. Moreover North West Frontier Province has been renamed as Khyber Pukhtunkhwa. The corrected spellings of Balochistan and Sindh and renaming of Khyber Pukhtunkhwa mark the effort to please the regional political forces of the provinces through recognition of their ethnic identities. Thus the perpetual claim of different ethnic groups for the recognition of their identity has been accepted.

Akin to the compensations for the provinces and regional groups the smaller classes like the minorities also gained support from the Amendment. To give the representation to non-Muslims in the Senate the seats of Senate have been increased by four, the reserved seats for the non-Muslims. When the next Senate election will be held after the approval of eighteenth amendment, for the first time in Pakistan one senator from each province will represent the non-Muslims.

\section{Empowering Parliament, Senate}

The remarkable success of the $18^{\text {th }}$ Amendment can be marked in respect of empowerment to the democratic institution of parliament that has been made more powerful in many ways. Joint sitting of the Parliament has been authorised with the power to decide on holding of the referendum suggested by the Prime Minister. Before eighteenth amendment Parliament only laid down the procedure of the referendum and compiling and consolidation of its results. Also the legislation process has been narrowed down to the Parliament only. In this respect the governmental control on the passage of the legislation through a mediation committee has been finished. The process now simply gives power to each house of Parliament or joint session of the Parliament to pass or reject any legislation. Moreover the time limit given to the President for consideration on the bill passed by the Parliament has been decreased from 30 days to 10 days.

Besides increase in legislative powers, the Parliament has been made stronger in other ways. Regarding imposition of emergency, if the President decides to impose emergency, the proclamation of emergency will be placed before both houses of the parliament for approval within ten days. Likewise the Council of Common Interest is not only responsible to the Parliament, as before, but it also will have to submit its annual report for the consideration of the both houses of Parliament. Similarly it is obligatory for NEC to submit its annual report 
to the Parliament. Moreover the Parliamentary committees will have vital role in appointments of judges and Election Commissioner.

Especially the role of Senate in various matters has been enhanced. When Senate's role increases the voice and desires of all units of the Federation will find proper chances to get fulfilment because Senate represents all of the units of the federation. While increase has been made in the working days of the Senate from 90 to 110, the president is bound to lay a report on the observance and implementation of the Principles of Policy not only before the National Assembly as already was the case but also before the Senate. Thus now both houses of the parliament would be able to discuss the report of the president on the Principles of Policy. The Cabinet shall be collectively responsible to the Senate as well it was to the National Assembly. The time of Senate's consideration on the bill of budget has been increased from 7 days to 14 days. This will increase the quantity and quality of the debate in the Senate.

Power of President to promulgate ordinance has also been limited by including a restriction that he can promulgate the ordinance only when Senate as well as National Assembly also is not in session. In the previous arrangement he could promulgate ordinances when National Assembly alone is not in session. The Senate like National Assembly will also be sent the report of Auditor General to be considered.

\section{Presidential Powers Curtailed}

One of the extraordinary fulfilments of the $18^{\text {th }}$ Amendment is that the powers of the President have been curtailed and the Prime Minister has been empowered more like he was in constitution 1973. The powers delegated to the President, through later amendments in the constitution made under General Zia-ul-Huq and General Musharraf, have been abolished. Instead of vesting the executive authority of the Federation in the President, this authority would be exercised by the Federal Government in the name of President. The Federal Government will consist of the Federal Minister and Prime Minister who would be the Chief Executive of the Government. The President shall not appoint or invite Prime Minister to hold office. On the other Prime Minister would be elected with simple majority of the National Assembly.

Prime Minister is no longer bound to the duties in relation to President for communication of the cabinet decisions, information of the administration and information about the decisions of Prime Minister as well as of his ministers. He is only to keep the President informed on internal and foreign policy and about legislative proposals. The President, according to the article 48 functions in accordance with the advice of the Cabinet or the Prime Minister. He could require reconsideration of the advice. The eighteenth amendment has restricted him to ask the reconsideration within fifteen days. Moreover President will have to act on the reconsidered advice within ten days. This restriction of the time limit will decrease the discretion of the President and the advice of the Prime Minister and Cabinet would have more weight.

Presidential powers of dissolution of the National Assembly have also been curtailed. The dissolution is discretionary power of the president only when vote of confidence has been passed against the Prime Minister and no other member of the National Assembly commands the confidence of National Assembly. In other conditions the discretionary power of the President to dissolve the National Assembly, as in 58(2)(b), have been deleted and for dissolution of the Assembly the President will have to follow the advice of the Prime Minister or Cabinet. He, after dissolution, will have to fix a date of election within ninety days and appoint a care-taker Prime Minister and Cabinet but it would not be his discretionary right. He will have to select the caretaker Prime Minister and cabinet after consultation with the Prime Minister and the Leader of Opposition in outgoing Assembly. Even further members of the cabinet will be appointed by the President on the advice of the caretaker Prime Minister.

The Prime Minister is compulsorily the chairman of the Council of Common Interest. The appointment made by the President would only be nominal as all of the members of the Council have been clearly mentioned in substituted article 153. Likewise the constitution of National Economic Council will not be the jurisdiction of the President as before. Four members from each province would be nominated by the Chief Minister of the respective province, and the Prime Minister will nominate four other members. For the appointment of the Auditor General, the President is bound to appoint the most senior officer in the office of the Auditor-General and he is no longer free to direct any one to work as auditor general. The authority of appointment for the Election Commission in the discretion of the President has also been seized and he is just to declare the names finalised by the parliamentary committee formed to recommend final appointment.

Moreover the appointments of the Chairman, Joint Chiefs of Staff Committee, the Chiefs of Army, Naval and Air Staffs, the Chairman of the Public Service Commission would be made by the President but not in his discretion and on advice of the Prime Minister. The President will appoint the Governor of any province not after 
consultation but on advice of the Prime Minister. The powers of the President to influence on the provincial governments through his appointed governors have been limited more as the governors have been grabbed of the powers in the province like the President in the Centre.

The legislative powers of the President also suffered a setback. The discretionary power of holding referendum on any matter of national importance has been grabbed from the President. Now this decision would be made by the Prime Minister with the approval of joint sitting of the Parliament. Thirty-five laws in Sixth Schedule which could not be altered, repealed or amended without the previous sanction of the President have been made open to altered, repealed or amended as the 268 (2) which mentioned this restriction has been omitted. Through this the important and major laws which are open for amendments without any prior influence include the National Accountability Bureau Act 1999, The Local Government Ordinances 2001 of all the four provinces, the Election Commission Order, 2002, and the Political Parties Order 2002.

\section{A Limit to Cabinet Members}

A step that has attracted praise from all circles is the putting a limit on the number of the Cabinet members. By limiting the strength of the members of cabinet to 11 percent of the total number of parliamentarians and by limiting the number of advisers for the Chief Ministers to 5 although the amendment has made it difficult for the ruling parties to keep the independent members in their fold through bribing them with ministries yet this will decrease the burden on the exchequer through deduction of the expenses on a large number of ministers who are included in the cabinet just to fulfil the political necessities of the government.

\section{Caretaker Cabinet and Election Commission}

A new arrangement which will strengthen the impartiality in the system is that the caretaker Prime Minister and members of caretaker cabinet shall not be eligible to contest the elections during the period when they would be in power. Besides their immediate family members - spouse and children - will also not be eligible to contest the elections under them. This will enhance the impartiality in the elections and the caretaker government would interfere less in the elections. Similarly in order to make the election of the Prime Minister and Chief Ministers more transparent their elections would not be held by secret ballot. There are chances and has been also a practice that, in the secret elections of the Prime Minister, the sympathies of the members can easily be purchased or influenced.

Another outstanding innovation introduced in the eighteenth amendment is the procedure for appointment of the Chief Election Commissioner and other four members of Election Commission of Pakistan. For appointments of Election Commission the Prime Minister after consultation with the leader of opposition in the National Assembly shall forward three names to the parliamentary committee which will confirm one name. The maximum 12 members-Committee would be constituted by the Speaker of National Assembly and comprise at least one third members from Senate and having 50 percent representation from opposition and treasury benches each. The members from opposition parties would be nominated by the respective parliamentary leaders based on their strength in the parliament. If the National Assembly would be dissolved committee would comprise members from Senate only.

\section{Other Changing}

Another prominent work of the $18^{\text {th }}$ Amendment is that Islamabad High Court, which was established by an order of General Musharraf during the lawyers' movement, has been established now through the constitutional law. And another notable thing is that the bar on prime ministers standing for only two terms in office has been removed - allowing opposition leader Nawaz Sharif, who was toppled by Musharraf in 1999, to again become premier.

Some obscurities in the Constitution have also been removed through the Amendment. The obscure application of condition for a Member of Parliament of being sagacious, righteous, non-profligate, honest and ameen has been made obvious and now a contrary declaration of any court in this respect would decide for this disqualification. Likewise conviction from any court on the crime of act against the ideology, security and integrity of Pakistan, defamation and ridicule of judiciary has been conditioned with the conviction of the court.

Lastly the $18^{\text {th }}$ Amendment can also boast of some interesting corrections in the constitution. These corrections are of the grammatical nature. For example the pronoun 'he' was used for the women seats in clause 62(b)(ii). The amendment corrected it with proper 'she'. Likewise unnecessary 'alone' in 25(2) was omitted.

Notwithstanding the achievements described above the Eighteenth Amendment has opened the doors of new controversies which have posed altogether new challenges for the policy makers. It has really buried many disagreements in the constitution but many new ones have emerged suddenly from it. First to mention is a fear of 
threat to the democratic institutions from the authoritarian forces. While the government and political parties are celebrating the victory of their unity for the amendment, some of the political analysts are anxious of the situation. The unity of the political parties, the analysts view, will make the establishment and potential dictators to react in the same way as they reacted to Z. A. Bhutto over his endeavour for managing consensus on the constitution 1973. (Khan, 2010)

\section{Danger to Democracy!}

The discussion has started that a danger to the democracy from within has once more been created as for the emergencies the 'safety valve' of the dissolution of National Assembly by president has gone. It means the soft option for an ambitious or angry army chief is gone. Sans the 58(2)(b) route, he will be left to grow more ambitious and angrier - and with only one option. A strong view is that given our history, perhaps the Musharraf version of 58(2)(b) makes more sense: the Supreme Court has to validate a presidential dissolution of the National Assembly within 45 days. (Almeida, 2010) Another point of view is that instead of judicial check on the powers of president, the political check is required. Article 234 already caters for such contingencies in a province. It is observed that an appropriate mechanism was needed at the federal level. Twice in our recent history, Pakistan had all-powerful Prime Ministers who enjoyed large majorities in the Parliament. They were both toppled by military coups d'état, which in turn wreaked havoc in the country. (Ezdi, 2010a) One check also is suggested that after having exercised this power, the President should be obligated to seek a vote of confidence from the newly elected National Assembly, failing which he or she should be stripped out of power.(Akhtar, 2010)

\section{Politicians and Political Parties}

A question has arisen on an addition in the Constitution about qualification of a convicted politician. The addition describes that elapse of five years after conviction will change the unqualified person into qualified one. Again the persons dismissed and removed or compulsorily retired would qualify after the period of five and three years respectively. Apparently these provisions have been added to give relief to those politicians who were convicted during the military regimes but it will become a permanent shelter for the persons who are proved convicted on the charges of corruption, dishonesty and opposition to the ideology of Pakistan and after the passage of five years will again be able to contest the elections.

The voting or abstaining to vote on a Constitution Bill against the policy of the political party has been included in the list of causes to disqualify a parliamentarian on ground of defection from the political party. Moreover the declaration of defection from the party has been designated to the Head of the political party in place of Head of the Parliamentary Party because the leaders of political party may be different than the leaders of the parliamentary party in the houses of parliament. Notwithstanding this law will come into effect from the next general elections, the party leaders outside the parliament have been strengthened through this law. While this law can increase the hold of leader of political parties, it can also develop party culture and prohibit flour crossing. If the elections within the parties are held regularly and fairly, these laws can establish a valuable political culture in the country. But many critics have expressed doubt on the motive of the politicians. It is observed that the deletion of the condition of the elections within parties is a move only to please the present leaders of the political parties.

The amendment has put a huge responsibility on the heads of the leaders of the political parties. It, in fact, has transferred the power of deposing the Prime Minister from President to the leader of the majority party. The power that the party chiefs may recall those members who deviate from the party line will constantly haunt the prime minister as much as the leader of the opposition. The significance of few party leaders in contrast with the members of party as well as parliament could be observed even during the process of the passage of amendment. The law-makers had to do less than did the few nominated members of the parliamentary committee in formation of the amendment. All of the members of parliament had just to endorse without speaking in favour or against what the leadership of the party had approved.

\section{Concurrent List}

Though for the first time in the country's judicial history a consensus has emerged on reshaping the precincts of provincial autonomy by abolishing all items from the Concurrent List - the list of legislative subjects which appeared in the Fourth Schedule to the constitution and mandated that the subjects mentioned therein could be legislated on by both the federal and the provincial legislatures - and handing them over to the provinces, (Hassan, 2010) the abolition, will confront the country with innumerable new challenges. Pakistan throughout its constitutional history, despite adopting three different constitutions, maintained the framework of legislation with concurrent list. The omission of the concurrent list now would involve the dismantling of large parts of the federal 
government and would deprive the federation of legislative powers in many areas which had been regulated at the national level in past.

The measure of abolition of the concurrent list for the sake of giving more autonomy has produced a controversy. It is an effort to search for middle way, and making every party to compromise to some extent. A debate already has started that it is not the answer to the demand for greater provincial autonomy and it will weaken the federal government without adding anything to the powers of the provinces.(Ezdi, 2010b) Autonomist parties also are not satisfied with the autonomy given to the provinces with the abolition of concurrent list. The notes of reiteration written by autonomist parties on the subject of autonomy mark the dissatisfaction saying that they wanted only four subjects with the federal government. The Sindh Nationalist and Progressive Alliance called a strike against the amendment and rejected the autonomy provisions. (Dawn, 2010, April 5)

The Centrist parties too are unhappy dew to altogether abolition of concurrent list. S. M. Zafar, (2010) one of the founding fathers of constitutions of Pakistan, has observed that the impression that there was any commitment by the founders of 1973 Constitution to omit concurrent list altogether on or after ten years is not borne by any historical record. Some experts too did not support the abolition of the concurrent list suggesting an alternative route for transferring the subjects and funds to the provinces without driving a stake through the concept of good governance. They proposed to examine the provisions of Article 146 of the constitution which permitted the federal government to transfer any functions and responsibilities falling within its purview to the provincial governments and also transfer the resources necessary for this purpose to the provinces. (Anwer, 2010) Another proposal was that autonomy would best be achieved not by scrapping the Concurrent List but by transferring those subjects from the Federal List to the Concurrent List on which the provinces want to have a greater say. (Ezdi, 2010a)

Now a new type of conflict among the province regarding the powers of these items may arise and also a new type of framework in respect of these subjects among the provinces and the Centre will have to be developed. The new set up requires the provincial governments to be more mature than in the past. Now they have been delegated with the powers in the areas where the Federal Government could come to their help in past. The provincial governments will have to show a sense of responsibility for incurring expenditures related to enhanced social welfare, provision of essential facilities to the poorest segments of the population, increasing levels of efficiency, or reducing levels of graft etc. By transferring a number of legislative subjects to the provinces (along with the funds currently allocated to them) with the provision that hence forward the provincial governments, which are already badly strapped for financial resources, would be responsible for incurring expenditures which the federal government was bearing.(Anwer, 2010)

By adorning the Prime Minister with the powers of appointing governors and service Chiefs, he has been vested with greater responsibilities. In this way the merit may be slain on the altar of expedience. Favouritism, which was could be practiced by the president in the past can develop in the hands of Prime Minister. The Prime Minister in the future will have to exercise this power carefully in the interest of the nation.

\section{People's Problems}

A severe criticism on the $18^{\text {th }}$ amendment has been made on the plea that it did not answer to people's problems. Ghinwa Bhutto said that that her party would support only those amendments which guaranteed people's control of police and revenue departments. (Dawn, 2010, April 5) Considering it purely a constitutional matter that arranged the benefits to the politicians and not to public a number of smaller parties with less or no representation in the Parliament objected over the enthusiasm of the major parties for the amendment. It was maintained that the amendment just paved the way for the head of PML-N to be elected as the Prime Minister for third term.

\section{Appointment of Judiciary}

The signing of the amendment bill by the committee was earlier scheduled for March 24, but these were the objections of the PML-N on issues of judges' appointment and renaming of the NWFP which made it put off for following week. (Hassan, 2010) Even the acceptance of PML-N did not decrease the criticism on the issues. The issue of renaming the North West Frontier Province (NWFP) with Khyber Pukhtoonkhwa gave rise to some new controversies relating to the formation of new provinces. Especially the issue of formation of Hazara province took a very dangerous turn when the violent protests of the movement raised for this purpose led to the killings of seven protesters just a day before the Eighteenth Amendment was about to be put in the Senate of Pakistan. The senators, therefore, in their debate expressed for the need to bring the nineteenth amendment in the constitution for settlement of this issue. The debate of creation of new provinces has severely emerged during and after the considerations on the amendment. Notwithstanding the demand of creation of a new Seraiki province was not discussed during the considerations of the committee, it was raised publically by some parliamentarians and 
political leaders of area. Some members of parliament from this region announced that they would not vote in favour of a constitutional package that does not provide for a new Seraiki province. (Ezdi, 2010b)

The procedure for appointments of judiciary opened new vistas of controversy. While the appointment of Chief Justice of Pakistan is continued to be made by President of the senior most judge of Supreme Court, an altogether new procedure has been introduced for the appointment of the judges of Supreme, High and Shariat courts. A Judicial Commission, consisting of the Chief Justice of Pakistan, two senior judges of Supreme Court, a former judge or Chief Justice nominated by the Chief Justice, attorney general, Minister for law and a nominated lawyer from Pakistan Bar Council, would nominate one qualified person for one vacancy to be appointed as judge. The recommendation of judicial commission would be viewed by a parliamentary committee formed of eight parliamentarians equal from both houses and from government as well as opposition nominated by the leader of houses and leaders of opposition. The members of the Commission and Committee will be taken from the provincial judiciary and provincial governments as well as assemblies respectively in the case of appointment of the judges of high court. The parliamentary committee can reject the nomination of judicial commission by three-fourth majority. The president will appoint the person nominated by judicial commission and confirmed by the parliamentary committee.

The critical point, as pointed out by some leading legal experts, is that it would politicise the process of appointment of judges, both at the nomination and the approval stages. A judge would have to cross not one but two hurdles: first a vote in the judicial commission and then one in the parliamentary committee. Votes in both these bodies will be cast on the basis of political affiliation and will become public. A judge who is appointed after going through this process will always be affiliated in the public perception with a particular political party. Besides, the provision that the senior-most judge will become the chief justice is also objectionable because it means that the appointment to the highest judicial office will depend only on length of service, irrespective of other relevant criteria such as competence and performance. (Hassan, 2010)

\section{Conclusion}

All said and done, the Amendment is an important milestone in the constitutional history of Pakistan. It marks a second twist towards democracy after the constitution-making in 1973. A consensus has been developed for the strength of federation through increase in the strength of the units. The Parliament has been empowered more than before. The functions and structure of the Parliament - especially the Senate - election commission and judiciary have been reshaped on institutional basis. No doubt some controversies have appeared, which are often the part of democratic decisions but with the developments following better results will appear.

\section{References}

Akhtar, Humayun. (2010, April 4). Some reflections on the 18th amendment. Dawn.

Almeida, Cyril. (2010, March 26). Change, but for the better? Dawn.

Anwer, Khalid. (2010, January 20). One System, Not Four. Dawn.

Ezdi, Asif. (2010a, February 18). Reforming' the constitution, Part II. The News.

Ezdi, Asif. (2010b, March 15). A Flawed Constitutional Package. The News.

Hassan, Ahmad. (2010, April 1). Parties Strike Accord on 18th Amendment. Dawn.

Khan, Tahir Hasan. (2010, April 5). 18th Amendment: Expectations Run Parallel with Dangers. The News.

Malik, B. A. (2010, April 18). 18 ${ }^{\text {th }}$ Amendment and Way Ahead. Dawn.

Tharani, Dr. Hasan. (2010, April 5). Letter to the Editor, Dawn.

Zafar, S. M. (2010). Note of Reiteration. Report of the parliamentary Committee on Constitutional Reforms, D-I. 